\title{
Evaluation of Electrocardiographic Parameters Predicting Cardiovascular Events in Patients with End-Stage Renal Disease before and after Transplantation
}

\author{
Laura Buerschaper ${ }^{a}$ Jürgen Floege ${ }^{a}$ Anja Mühlfeld ${ }^{a}$ Georg Schlieper ${ }^{a}$ b \\ aDepartment of Nephrology and Clinical Immunology, University Hospital RWTH Aachen, \\ Aachen, Germany; b Zentrum für Nieren-, Hochdruck- und Stoffwechselerkrankungen, \\ Hannover, Germany
}

\section{Keywords}

End-stage renal disease $\cdot$ Electrocardiogram $\cdot$ Cardiovascular events $\cdot \mathrm{T}$-wave $\cdot \mathrm{T}: \mathrm{R}$ ratio

\begin{abstract}
Background and Objectives: Cardiovascular (CV) mortality represents the leading cause of death in patients with end-stage renal disease (ESRD). Efficient screening is required to detect $\mathrm{CV}$ disease at an early stage, but the best diagnostic work-up is uncertain. The aim of this study was to identify electrocardiographic parameters in dialysis patients associated with an increased frequency of CV events. Methods: A 12-lead electrocardiogram was performed in 139 patients who were on the renal transplant waiting list and who subsequently received a kidney transplant. CV events were analyzed from the day of listing for kidney transplantation until 1 year after renal transplantation. Results: Multivariate Cox regression analysis showed that an elevated $T: R$ ratio in anterior and inferior leads was independently associated with CV events ( $\mathrm{T}: \mathrm{R}$ ratio of anterior leads hazard ratio $[H R] 1.32[95 \% \mathrm{Cl} 1.09-1.59 ; p=0.004]$ and inferior leads HR 2.15 [95\% Cl 1.23-3.77; $p=0.008]$ ). In particular, a T:R ratio in inferior leads exceeding 0.6 was associated with CV events in a Kaplan-Meier analysis. Conclusions: Taken together, we found an increased T:R ratio in ESRD patients to be a predictive marker for CV events.
\end{abstract}

\section{Introduction}

Patients with end-stage renal disease (ESRD) exhibit a high risk of cardiovascular (CV) disease (CVD) contributing to increased morbidity and mortality [1,2]. Arrhythmias and cardiac arrest are among the leading causes of CV mortality in these patients [1]. Especially 


\section{Kidney \\ Blood Pressure \\ Research}

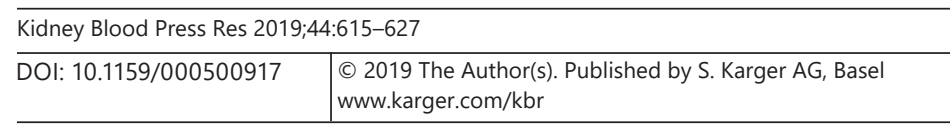

Buerschaper et al.: ECG and CV Events in ESRD

the period patients are treated by dialysis awaiting transplantation until 1 year after transplantation is known to be associated with the highest incidence of CVD [3-6].

Efficient screening including an easily accessible screening tool is required to detect CVD at an early stage in such patients. Electrocardiography (ECG) represents a noninvasive, widely available, easily accessible, and inexpensive test and might thus be a useful tool in predicting CV events [7-9].

Several studies have assessed ECG parameters in hemodialysis patients and their association with CV events. A number of ECG parameter abnormalities have been described including signs of left ventricular hypertrophy, ischemic changes, rhythm disturbances, and repolarization abnormalities $[10,11]$. Also, association between various ECG parameter changes with increased CV morbidity and mortality and all-cause mortality has been presented, that is, left ventricular hypertrophy by different scoring systems, increased heart rate, atrial fibrillation, PR-interval and QTc interval prolongation, and T-wave changes [10, 12-20]. However, studies on ECG alterations in dialysis patients found rather poor sensitivity and specificity in predicting coronary artery disease [21]. To further analyze the prognostic value of standard ECG in ESRD patients, we decided to perform a thorough ECG evaluation including all standard ECG parameters, which are evaluated in daily routine. Special emphasis was placed on T-wave changes in this study, since this ECG parameter had received relatively little attention in prior studies despite the fact that T-waves are frequently altered in ESRD patients [20,22].

Thus, the aim of our study was to identify specific ECG parameters that can serve as predictors of future $\mathrm{CV}$ events in dialysis patients on the transplant waiting list.

\section{Materials and Methods}

\section{Study Population and Examination}

In our retrospective cohort study, we analyzed 196 patients who received a kidney transplant at the RWTH Aachen University Hospital between January 2004 and December 2010. Twenty-one patients were excluded due to missing transplantation files, 27 patients had to be excluded since ECGs were unreadable due to bleaching, eight patients whose ECGs were recorded after transplantation and 1 patient with complete bundle branch block. Finally, 139 patients were included in the final cohort (Fig. 1). All patients were analyzed, regardless of whether they received a deceased or living donor kidney and whether they previously had been treated with hemodialysis or peritoneal dialysis.

Clinical history, such as general patient information consisting of age, gender, body mass index (BMI), and smoking status were collected. In addition, data on previous diagnoses including preexisting CV events, cardiac arrhythmia, and presence of left ventricular hypertrophy and congestive heart failure measured by echocardiography were saved. Also, medication and serum biochemistry obtained at the time of transplant listing, as well as data concerning kidney failure and time on dialysis were analyzed. Subsequently, information about the transplant kidney function and the immunosuppressive regime was collected on the day of discharge after transplantation as well as 1 year thereafter.

\section{Outcomes}

CV events included myocardial infarction, coronary bypass surgery, coronary stent implantation, stroke, and interventions in patients with peripheral artery disease. Our period of observation started on the day of listing for renal transplantation and ended 1 year after transplantation, since this period is described as being associated with the highest incidence of CVD [3-6].

\section{ECG Evaluation}

Basic ECG Evaluation

Standard 12-lead electrocardiograms had been obtained in all patients at the time of entering the waiting list for transplantation. These ECGs were retrospectively analyzed. The following measurements were taken: heart rate, the PR interval, QRS complex duration, and QTc interval adapted by Bazett's formula. Heart axis, R/S transition, 


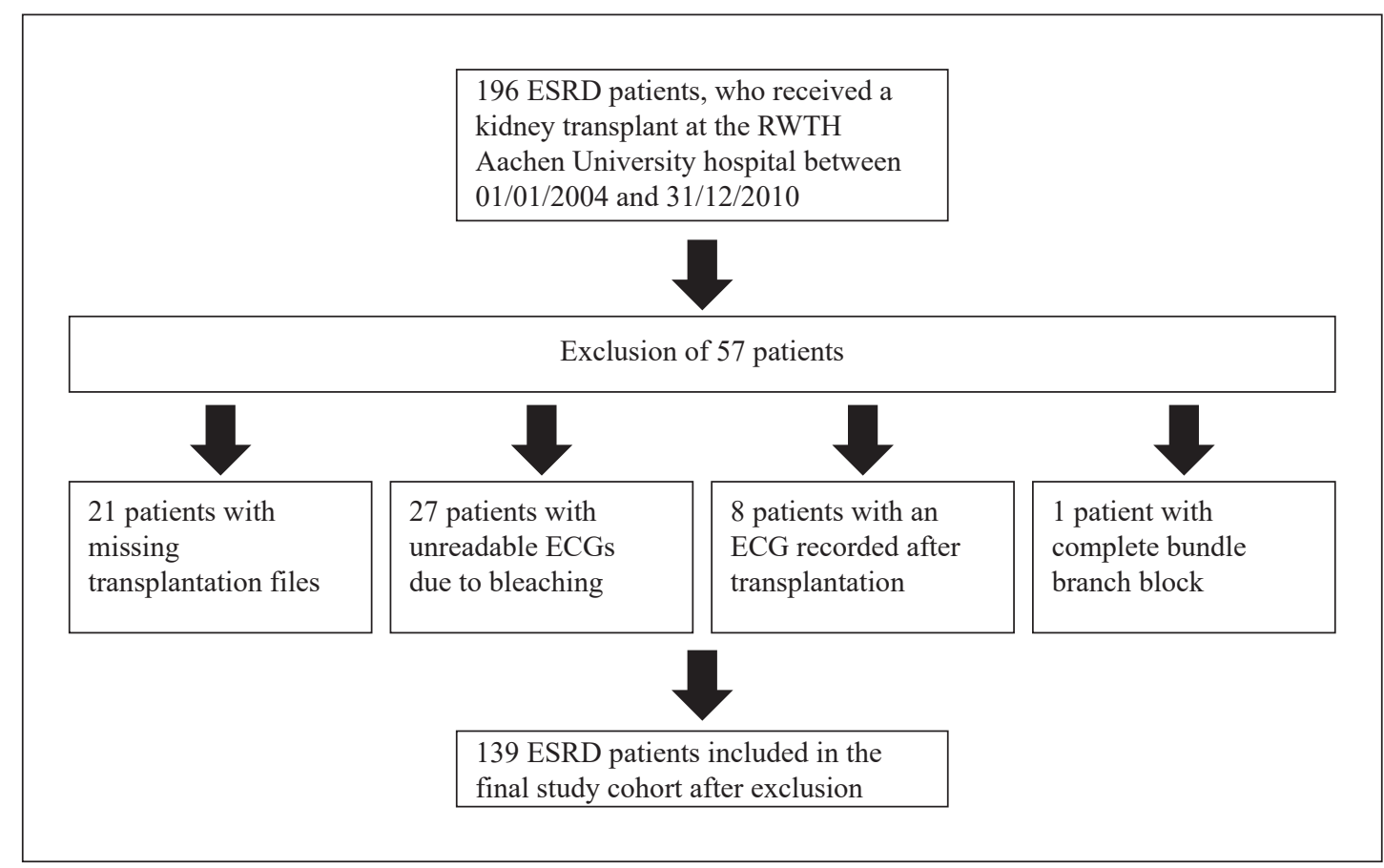

Fig. 1. Flow chart illustrating reasons for inclusion and exclusion into our study cohort. ESRD, end-stage renal disease; ECG, electrocardiography.

as well as P-wave height and length and T-wave morphology adjusted by the ratio of T-wave to R-wave were also evaluated. In addition, all ECGs were analyzed for atrial fibrillation, AV-block, bundle branch block, ischemic changes, extrasystoles, and evidence of left or right ventricular hypertrophy using the Sokolow-Lyon index.

Analysis of T-Wave Morphology

To identify repolarization abnormalities, manifested by altered T-waves, we created groups representing different regions of the heart. The anterior part of the heart was represented by leads V2-V4; the lateral part by leads V5, V6, I, and aVL; and the inferior section of the heart was represented by leads II, III, and aVF. We calculated the ratio of T-wave to R-wave in order to evaluate the repolarization process without the influence of possible confounders. For this purpose, the height of the T-wave is usually studied in relation to the R-wave amplitude expressed by the $\mathrm{T}$ : $\mathrm{R}$ ratio $[23,24]$. T-wave abnormalities were categorized into a flattened T-wave measuring less than $1 / 8$ of the R-wave, an elevated T-wave measuring more than $2 / 3$ of the R-wave and T-wave inversion, which additionally was divided into preterminal and terminal negative waves.

\section{Statistical Analysis}

Data were collected and analyzed using SPSS software for Windows (version 25, SPSS Inc., Chicago, IL, USA). Continuous variables are depicted as mean values and associated standard deviation. Categorical data are presented as relative frequencies and percentages. Comparison between 2 groups was calculated using $\chi^{2}$ test for categorical data. Continuous data were compared using the $t$ test for normally distributed data and the Mann-Whitney U test for skewed data. Correlation with various parameters was performed using Pearson correlation for normally distributed data and rank correlation for skewed data. Cox analysis was used to determine which ECG parameters correlated with CV events with a value of $p<$ 0.05 considered to be statistically significant. In order to screen for possible confounders, multivariate statistical analysis with adjustment for age, sex, diabetes, potassium, and additional parameters was performed. To identify a significant threshold of the T:R ratio for predicting CVD, a Kaplan-Meier survival curve was calculated. 
Kidney

Blood Pressure

Research
Kidney Blood Press Res 2019;44:615-627

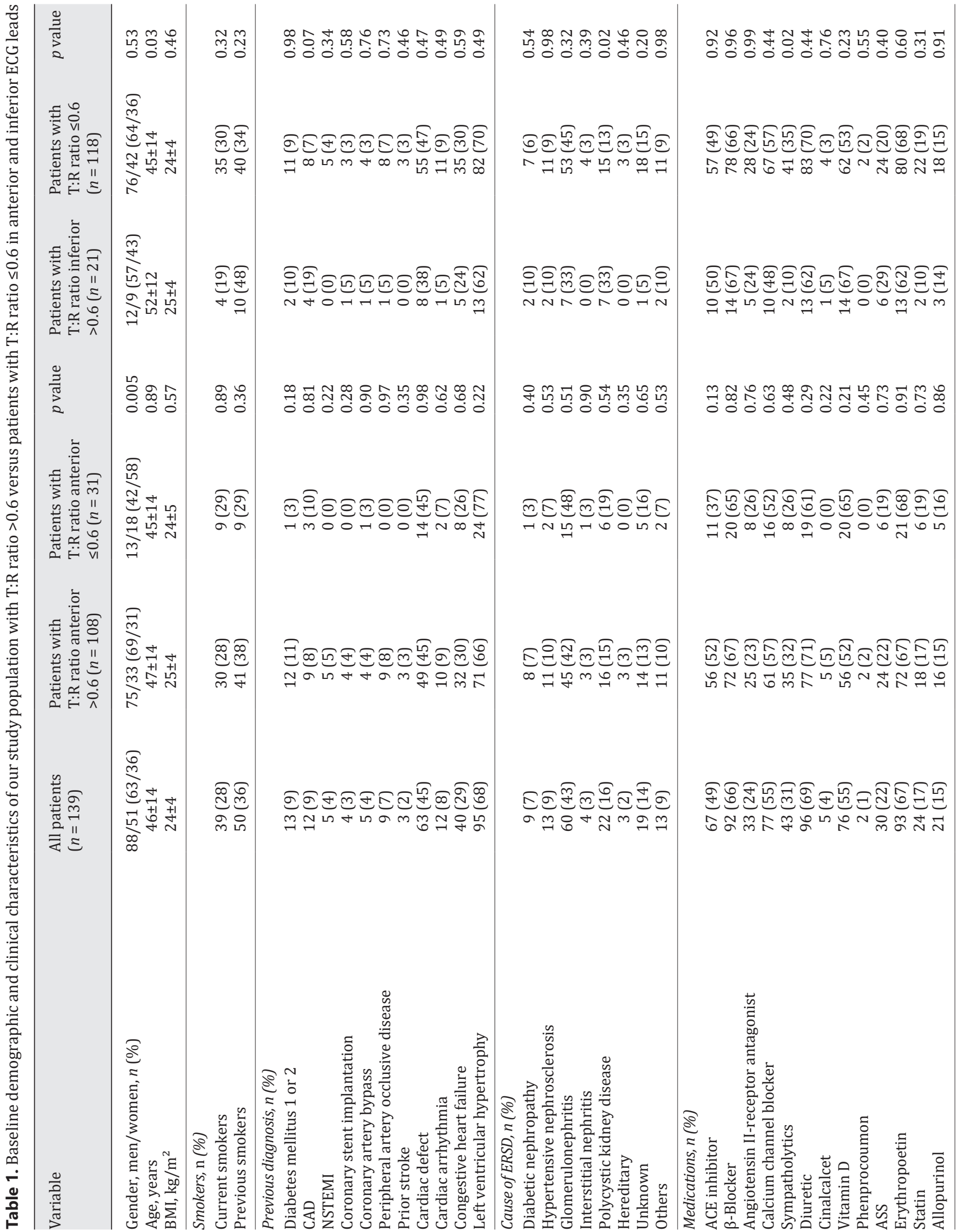


Kidney
Blood Pressure

Research

\begin{tabular}{l|l}
\hline Kidney Blood Press Res 2019:44:615-627 \\
\hline DOI: 10.1159/000500917 & $\begin{array}{l}\text { ○ 2019 The Author(s). Published by S. Karger AG, Basel } \\
\text { www.karger.com/kbr }\end{array}$ \\
\hline
\end{tabular}

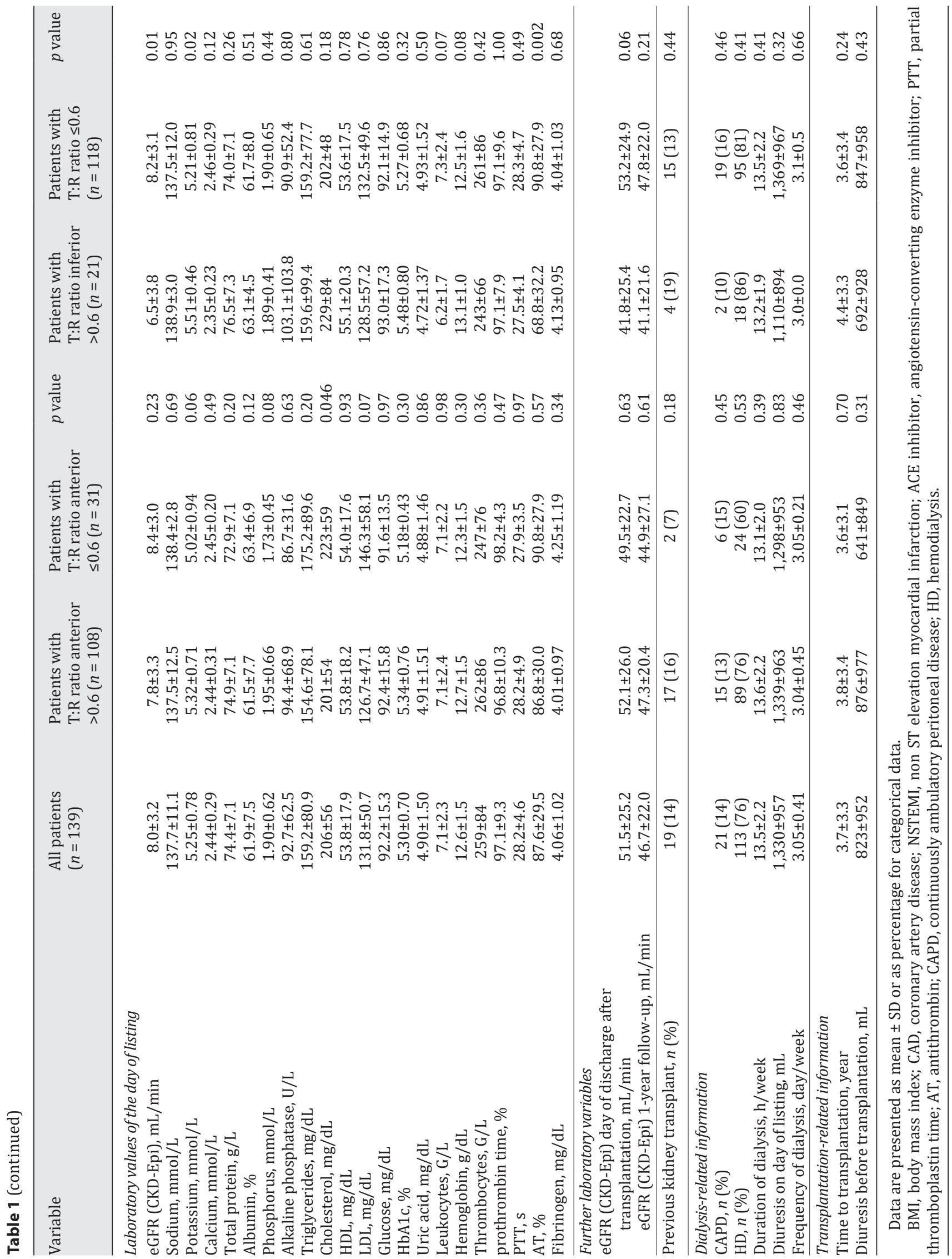




\section{Kidney \\ Blood Pressure \\ Research}

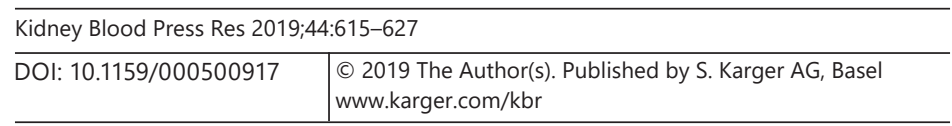

Buerschaper et al.: ECG and CV Events in ESRD

Fig. 2. Timeline of the time of observation starting at registration for waiting list and ending on the day of 1-year follow-up after transplantation.

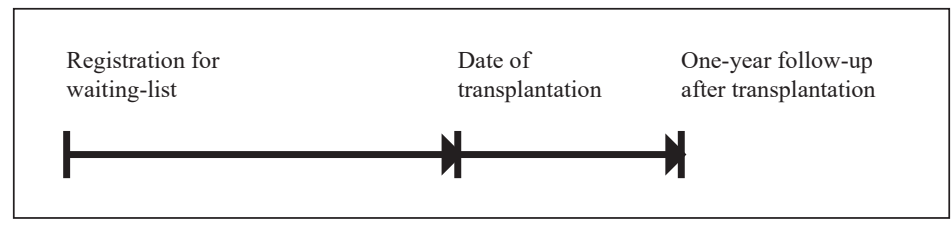

\section{Results}

\section{Baseline Characteristics}

Patients' characteristics, previous diagnoses, causes of ESRD, medications, and laboratory variables of the day of listing are presented in Table 1. Furthermore, dialysis- and transplantation-related information is demonstrated (Table 1).

\section{Major CV Events}

We retrospectively analyzed 139 patients from the time of listing for renal transplantation until 1 year after transplantation as shown in Figure 2. The observation period covered $4.7 \pm 3.5$ years. During this time, 1 patient developed an ST-elevation myocardial infarction, twelve patients were recorded with non ST-elevation myocardial infarctions, 3 patients received coronary stent implantations, 1 patient underwent coronary bypass surgery, 1 patient presented with a stroke, and 5 patients had to undergo an intervention for peripheral artery disease. In total, 22 patients (16\%) thus suffered CV events during our period of observation. CV events occurred at a mean of $4.01 \pm 2.96$ years after transplant listing.

\section{ECG Evaluation}

Basic ECG Parameters

Results of our ECG evaluation are shown in Table 2. Patients who experienced CV events exhibited a significantly higher T:R ratio in anterior leads $(p=0.03)$ and significantly more ECGs with extrasystoles ( $p=0.001)$.

Among the ECG parameters evaluated, the T:R ratio showed a significant association with $\mathrm{CV}$ events in dialysis patients awaiting a kidney transplant until 1 year after transplantation. To investigate repolarization abnormalities in more detail, we analyzed the T:R ratio in different regions of the heart. An elevated T:R ratio was seen in $76 \%$ of anterior leads and $14 \%$ of inferior leads.

Second, we correlated T:R values with the patients' clinical characteristics of the day of listing. In anterior leads a significant correlation was detected between T:R ratios and serum values for potassium ( $p=0.006$; correlation coefficient [CC] 0.163), phosphorus ( $p=0.04$; CC $0.118), \operatorname{HbA} 1 \mathrm{C}(p=0.03$; CC 0.129$)$, and total protein ( $p=0.01$; CC 0.148$)$, the patients' hemoglobin values ( $p=0.003$; CC 0.174$)$ and cinacalcet administration ( $p=0.004$; CC 0.242$)$. Also, a positive correlation between the T:R ratios in anterior leads and the group of patients treated by hemodialysis ( $p=0.02$; CC 0.209 ) was detected, whereas a negative correlation was found with the group treated by CAPD ( $p=0.02$; CC -0.204$)$. In inferior leads age ( $p=$ 0.04; CC 0.123) showed a significant correlation with the T:R ratio, whereas a significant negative correlation was detected with ACE inhibitor medication ( $p=0.04$; CC -0.180 ; online suppl. Material Table 1, see www.karger.com/doi/10.1159/000500917).

Univariate Cox Regression

Univariate Cox regression revealed the following parameters to be associated with CV events: age, BMI, serum calcium, serum cholesterol, prothrombin time, duration of dialysis, and time until receiving kidney transplantation (Table 3). 


\section{Research}

Buerschaper et al.: ECG and CV Events in ESRD

Table 2. ECG parameters of patients with versus without CV events

\begin{tabular}{|c|c|c|c|c|}
\hline Parameter & $\begin{array}{l}\text { All patients, } \\
(n=139)\end{array}$ & $\begin{array}{l}\text { Patients with CV } \\
\text { events, }(n=22)\end{array}$ & $\begin{array}{l}\text { Patients without CV } \\
\text { events }(n=117)\end{array}$ & $p$ value \\
\hline Heart rate & $70 \pm 15$ & $69 \pm 16$ & $70 \pm 15$ & 0.99 \\
\hline \multicolumn{5}{|l|}{ Heart axis, n (\%) } \\
\hline Left axis deviation & $7(5)$ & $2(9)$ & $5(4)$ & 0.34 \\
\hline Horizontal axis & $59(42)$ & $9(41)$ & $50(43)$ & 0.93 \\
\hline Normal axis & $44(32)$ & $9(41)$ & $35(30)$ & 0.31 \\
\hline Vertical axis & $23(17)$ & $2(9)$ & $21(18)$ & 0.31 \\
\hline Right axis & $3(2)$ & $0(0)$ & $3(3)$ & 0.45 \\
\hline Extreme right axis deviation & $2(1)$ & $0(0)$ & $2(2)$ & 0.54 \\
\hline SIQIIII & $1(1)$ & $0(0)$ & $1(1)$ & 0.66 \\
\hline Atrial fibrillation, $n(\%)$ & $1(1)$ & $0(0)$ & $1(1)$ & 0.66 \\
\hline p-Sinistrocardiale, $n(\%)$ & 37 (27) & $6(27)$ & 31 (27) & 0.96 \\
\hline PQ interval, s & $0.17 \pm 0.04$ & $0.16 \pm 0.05$ & $0.17 \pm 0.03$ & 0.88 \\
\hline AV-block, $n(\%)$ & $13(9)$ & $2(9)$ & $11(9)$ & 0.95 \\
\hline QRS interval, s & $0.08 \pm 0.02$ & $0.07 \pm 0.02$ & $0.08 \pm 0.01$ & 0.51 \\
\hline Incomplete BBB, $n(\%)$ & $8(6)$ & $2(9)$ & $6(5)$ & 0.46 \\
\hline Sokolow index left, mV & $2.89 \pm 1.27$ & $2.39 \pm 1.06$ & $2.96 \pm 1.25$ & 0.21 \\
\hline Sokolow index right, $\mathrm{mV}$ & $0.61 \pm 0.37$ & $0.49 \pm 0.31$ & $0.64 \pm 0.37$ & 0.31 \\
\hline \multicolumn{5}{|l|}{$R / S$ turnover, n (\%) } \\
\hline V1/V2 & $7(5)$ & $2(9)$ & $5(4)$ & 0.34 \\
\hline $\mathrm{V} 2 / \mathrm{V} 3$ & $33(24)$ & $5(23)$ & $28(25)$ & 0.90 \\
\hline V3/V4 & $69(50)$ & $9(41)$ & $60(51)$ & 0.37 \\
\hline V4/V5 & $25(18)$ & $4(18)$ & $21(18)$ & 0.98 \\
\hline V5/V6 & $2(1)$ & $1(5)$ & $1(1)$ & 0.18 \\
\hline No turnover & $3(2)$ & $1(5)$ & $2(2)$ & 0.40 \\
\hline ST segment changes, $n(\%)$ & $22(16)$ & $5(23)$ & $17(15)$ & 0.33 \\
\hline $\mathrm{T}: \mathrm{R}$ ratio anterior & $1.87 \pm 1.75$ & $2.91 \pm 2.61$ & $1.68 \pm 1.47$ & 0.03 \\
\hline $\mathrm{T}: \mathrm{R}$ ratio lateral & $0.007 \pm 0.62$ & $0.04 \pm 0.46$ & $0.001 \pm 0.65$ & 0.80 \\
\hline $\mathrm{T}: \mathrm{R}$ ratio inferior & $0.28 \pm 0.82$ & $0.66 \pm 1.27$ & $0.21 \pm 0.69$ & 0.23 \\
\hline QTc (Bazett's formula), ms & $400 \pm 47$ & $407 \pm 27$ & $399 \pm 49$ & 0.42 \\
\hline Extrasystoles, $n(\%)$ & $4(3)$ & $3(14)$ & $1(1)$ & 0.001 \\
\hline Supraventricular & $1(1)$ & $1(5)$ & $0(0)$ & 0.02 \\
\hline Ventricular & $3(2)$ & $2(9)$ & $1(1)$ & 0.02 \\
\hline
\end{tabular}

Data are presented as mean \pm SD or as percentage for categorical data.

$\mathrm{CV}$, cardiovascular; ECG, electrocardiography; BBB, bundle branch block.

When performing univariate Cox regression analysis concerning ECG parameters an elevated T:R ratio occurring in anterior and inferior leads $(p=0.001 ; 95 \%$ CI $1.14-1.64$ and $p=0.001 ; 95 \%$ CI 1.49-4.57), ECGs containing extrasystoles ( $p=0.005 ; 95 \%$ CI 1.74-20.93), as well as a decreased left and right Sokolow-Lyon index ( $p=0.02 ; 95 \%$ CI $0.39-0.91$ and $p=$ 0.03; 95\% CI 0.06-0.90), showed a significant association with CV events (Table 3).

\section{Multivariate Cox Regression}

We performed adjustment for several parameters. When adjusting ECG parameters for known potential confounders age, sex, diabetes, and potassium, the T:R ratio in anterior ( $p=$ 0.004 ; 95\% CI 1.09-1.59) and inferior leads ( $p=0.008$; 95\% CI 1.23-3.77) remained significantly associated with future CV events. Further multivariate adjustment also including BMI, 


\section{Kidney \\ Blood Pressure \\ Research}

Table 3. Univariate Cox regression analysis on $\mathrm{CV}$ events

\begin{tabular}{l|l}
\hline Kidney Blood Press Res 2019;44:615-627 \\
\hline DOI: 10.1159/000500917 & $\begin{array}{l}\text { @ 2019 The Author(s). Published by S. Karger AG, Basel } \\
\text { www.karger.com/kbr }\end{array}$ \\
\hline
\end{tabular}

\begin{tabular}{lcl}
\hline Parameter & $p$ value & HR $(95 \% \mathrm{CI})$ \\
\hline T:R ratio anterior & 0.001 & $1.37(1.14-1.64)$ \\
T:R ratio inferior & 0.001 & $2.61(1.49-4.57)$ \\
Extrasystoles & 0.005 & $6.03(1.74-20.93)$ \\
Sokolow index left & 0.02 & $0.60(0.39-0.91)$ \\
Sokolow index right & 0.03 & $0.23(0.06-0.90)$ \\
Age & $<0.001$ & $1.09(1.04-1.14)$ \\
BMI & 0.02 & $1.13(1.02-1.25)$ \\
S-Calcium & 0.046 & $0.14(0.02-0.97)$ \\
S-Cholesterol & 0.02 & $1.01(1.00-1.01)$ \\
Prothrombin time & 0.02 & $0.97(0.94-1.00)$ \\
Duration of dialysis & 0.02 & $1.24(1.04-1.49)$ \\
Days-transplantation & 0.02 & $1.00(0.99-1.00)$ \\
\hline
\end{tabular}

$\mathrm{CV}$, cardiovascular; BMI, body mass index.

serum potassium, calcium, cholesterol, prothrombin time, and estimated glomerular filtration rate (CKD-Epi formula) values at the time of listing and the day of discharge after transplantation as well as duration of dialysis and days to transplantation did not change the observed significance of the $\mathrm{T}$ : $\mathrm{R}$ ratio (Table 4 ).

\section{Kaplan-Meier Analysis}

To assess whether there is a threshold for predictive T:R ratios, we performed KaplanMeier analysis using different cutoff values. Setting the threshold at 0.6, a T:R ratio above 0.6 in inferior leads was significantly associated with future CV events ( $p=0.03$; Fig. 3a). In contrast, a Kaplan-Meier analysis of anterior leads with a T:R ratio $>0.6$ revealed no significant predictive value ( $p=0.16$; Fig. $3 \mathrm{~b}$ ). Values other than 0.6 resulted in lower predictive power (data not shown).

\section{Discussion}

In this study, we evaluated multiple ECG parameters for prediction of CV events in ESRD patients on the kidney transplant waiting list and found an increased T:R ratio as an independent predictor for CV events. Electrocardiographic abnormalities during the process of repolarization, as represented by T-wave changes, correlate with an increased susceptibility for cardiac arrhythmias in the general population $[25,26]$. Especially $\mathrm{T}$-wave alternans, that is, a beat-to-beat variation in T-wave amplitude, has been described as being associated with a high risk for sudden cardiac death and CV mortality [27]. In addition, an independent association of T-wave alternans with macrovascular disease has been reported [20]. These observations point to the importance of $\mathrm{T}$-wave abnormalities in predicting $\mathrm{CV}$ morbidity and mortality. Furthermore, T-wave changes are common in ESRD patients undergoing dialysis $[20,22]$.

In our study, we detected a T:R ratio $>0.6$ in inferior leads as being independently predictive for future CV events. To the best of our knowledge, association of CV morbidity and mortality and T:R ratio has been investigated in ESRD patients in only one previous study [24]. Green et al. [24] described a T:R ratio $>0.75$ as being independently predictive for sudden death in ESRD patients. In that study, ECGs of 145 ESRD patients were analyzed for T-wave tenting and $\mathrm{T}: \mathrm{R}$ ratios, their association with serum potassium, and their prognostic value 
Table 4. Multivariate Cox regression analysis on $\mathrm{CV}$ events

\begin{tabular}{|c|c|c|c|c|c|}
\hline Covariates & $\begin{array}{l}\mathrm{T}: \mathrm{R} \text { ratio } \\
\text { anterior } \\
p \text { value } \\
\text { HR }(95 \% \mathrm{CI})\end{array}$ & $\begin{array}{l}\mathrm{T}: \mathrm{R} \text { ratio } \\
\text { inferior } \\
p \text { value } \\
\text { HR }(95 \% \mathrm{CI})\end{array}$ & $\begin{array}{l}\text { Extrasystoles } \\
p \text { value } \\
\text { HR }(95 \% \mathrm{CI})\end{array}$ & $\begin{array}{l}\text { Sokolow index } \\
\text { left } \\
p \text { value } \\
\text { HR }(95 \% \mathrm{CI})\end{array}$ & $\begin{array}{l}\text { Sokolow index } \\
\text { right } \\
p \text { value } \\
\text { HR }(95 \% \mathrm{CI})\end{array}$ \\
\hline Age (years) & $\begin{array}{l}0.01 \\
1.25(1.06-1.49)\end{array}$ & $\begin{array}{l}0.006 \\
2.09(1.23-3.55)\end{array}$ & $\begin{array}{l}0.048 \\
3.52(1.01-12.24)\end{array}$ & $\begin{array}{l}0.29 \\
0.79(0.51-1.22)\end{array}$ & $\begin{array}{l}0.07 \\
0.28(0.07-1.13)\end{array}$ \\
\hline Gender & $\begin{array}{l}0.001 \\
1.37(1.14-1.64)\end{array}$ & $\begin{array}{l}0.001 \\
2.63(1.49-4.65)\end{array}$ & $\begin{array}{l}0.005 \\
6.03(1.72-21.10)\end{array}$ & $\begin{array}{l}0.02 \\
0.59(0.38-0.91)\end{array}$ & $\begin{array}{l}0.03 \\
0.21(0.05-0.87)\end{array}$ \\
\hline Diabetes & $\begin{array}{l}0.001 \\
1.37(1.14-1.64)\end{array}$ & $\begin{array}{l}0.001 \\
2.63(1.50-4.62)\end{array}$ & $\begin{array}{l}0.004 \\
6.27(1.78-22.09)\end{array}$ & $\begin{array}{l}0.02 \\
0.60(0.39-0.91)\end{array}$ & $\begin{array}{l}0.04 \\
0.23(0.06-0.90)\end{array}$ \\
\hline BMI & $\begin{array}{l}0.001 \\
1.36(1.32-1.62)\end{array}$ & $\begin{array}{l}0.001 \\
2.54(1.44-4.47)\end{array}$ & $\begin{array}{l}0.001 \\
9.64(2.57-36.17)\end{array}$ & $\begin{array}{l}0.06 \\
0.66(0.42-1.02)\end{array}$ & $\begin{array}{l}0.02 \\
0.17(0.04-0.71)\end{array}$ \\
\hline S-Potassium & $\begin{array}{l}<0.001 \\
1.44(1.18-1.76)\end{array}$ & $\begin{array}{l}0.001 \\
2.66(1.51-4.66)\end{array}$ & $\begin{array}{l}0.006 \\
5.97(1.67-21.38)\end{array}$ & $\begin{array}{l}0.02 \\
0.60(0.39-0.91)\end{array}$ & $\begin{array}{l}0.03 \\
0.19(0.04-0.82)\end{array}$ \\
\hline S-Calcium & $\begin{array}{l}0.001 \\
1.36(1.14-1.63)\end{array}$ & $\begin{array}{l}0.002 \\
2.36(1.36-4.12)\end{array}$ & $\begin{array}{l}0.005 \\
5.93(1.70-20.73)\end{array}$ & $\begin{array}{l}0.048 \\
0.65(0.43-1.00)\end{array}$ & $\begin{array}{l}0.04 \\
0.22(0.05-0.91)\end{array}$ \\
\hline S-Cholesterol & $\begin{array}{l}0.006 \\
1.31(1.08-1.60)\end{array}$ & $\begin{array}{l}0.001 \\
2.62(1.45-4.74)\end{array}$ & $\begin{array}{l}0.02 \\
4.48(1.25-16.08)\end{array}$ & $\begin{array}{l}0.02 \\
0.59(0.38-0.91)\end{array}$ & $\begin{array}{l}0.06 \\
0.26(0.06-1.04)\end{array}$ \\
\hline Prothrombin time & $\begin{array}{l}0.001 \\
1.36(1.13-1.63)\end{array}$ & $\begin{array}{l}0.001 \\
2.54(1.45-4.46)\end{array}$ & $\begin{array}{l}0.004 \\
6.32(1.80-22.13)\end{array}$ & $\begin{array}{l}0.03 \\
0.62(0.40-0.94)\end{array}$ & $\begin{array}{l}0.045 \\
0.23(0.05-0.97)\end{array}$ \\
\hline eGFR, day of listing & $\begin{array}{l}0.003 \\
1.33(1.10-1.60)\end{array}$ & $\begin{array}{l}0.002 \\
2.61(1.40-4.85)\end{array}$ & $\begin{array}{l}0.001 \\
9.53(2.53-35.86)\end{array}$ & $\begin{array}{l}0.01 \\
0.58(0.38-0.88)\end{array}$ & $\begin{array}{l}0.03 \\
0.23(0.06-0.88)\end{array}$ \\
\hline $\begin{array}{l}\text { eGFR, day of discharge } \\
\text { after transplantation }\end{array}$ & $\begin{array}{l}<0.001 \\
1.44(1.17-1.76)\end{array}$ & $\begin{array}{l}0.001 \\
2.68(1.51-4.75)\end{array}$ & $\begin{array}{l}0.006 \\
5.99(1.66-21.67)\end{array}$ & $\begin{array}{l}0.02 \\
0.61(0.40-0.93)\end{array}$ & $\begin{array}{l}0.04 \\
0.22(0.05-0.95)\end{array}$ \\
\hline Duration of dialysis & $\begin{array}{l}0.001 \\
1.43(1.16-1.77)\end{array}$ & $\begin{array}{l}0.002 \\
3.097(1.50-6.40)\end{array}$ & $\begin{array}{l}0.02 \\
6.89(1.45-32.69)\end{array}$ & $\begin{array}{l}0.04 \\
0.59(0.36-0.98)\end{array}$ & $\begin{array}{l}0.40 \\
0.52(0.11-2.36)\end{array}$ \\
\hline Days to transplantation & $\begin{array}{l}<0.001 \\
1.39(1.16-1.68)\end{array}$ & $\begin{array}{l}<0.001 \\
2.72(1.56-4.75)\end{array}$ & $\begin{array}{l}0.004 \\
6.25(1.78-21.92)\end{array}$ & $\begin{array}{l}0.02 \\
0.61(0.40-0.94)\end{array}$ & $\begin{array}{l}0.04 \\
0.22(0.05-0.90)\end{array}$ \\
\hline $\begin{array}{l}\text { Age (years) } \\
\text { Gender } \\
\text { Diabetes }\end{array}$ & $\begin{array}{l}0.009 \\
1.26(1.06-1.49)\end{array}$ & $\begin{array}{l}0.008 \\
2.11(1.22-3.65)\end{array}$ & $\begin{array}{l}0.06 \\
3.37(0.95-11.99)\end{array}$ & $\begin{array}{l}0.31 \\
0.80(0.52-1.23)\end{array}$ & $\begin{array}{l}0.07 \\
0.26(0.06-1.12)\end{array}$ \\
\hline $\begin{array}{l}\text { Age (years) } \\
\text { Gender } \\
\text { Diabetes } \\
\text { S-Potassium }\end{array}$ & $\begin{array}{l}0.004 \\
1.32(1.09-1.59)\end{array}$ & $\begin{array}{l}0.008 \\
2.15(1.23-3.77)\end{array}$ & $\begin{array}{l}0.08 \\
3.25(0.89-11.94)\end{array}$ & $\begin{array}{l}0.31 \\
0.80(0.52-1.23)\end{array}$ & $\begin{array}{l}0.06 \\
0.23(0.05-1.07)\end{array}$ \\
\hline $\begin{array}{l}\text { Age (years) } \\
\text { Gender } \\
\text { Diabetes } \\
\text { eGFR, day of discharge } \\
\text { after transplantation }\end{array}$ & $\begin{array}{l}0.002 \\
1.35(1.11-1.64)\end{array}$ & $\begin{array}{l}0.003 \\
2.40(1.34-4.31)\end{array}$ & $\begin{array}{l}0.17 \\
2.61(0.66-10.42)\end{array}$ & $\begin{array}{l}0.23 \\
0.76(0.49-1.19)\end{array}$ & $\begin{array}{l}0.06 \\
0.22(0.04-1.07)\end{array}$ \\
\hline
\end{tabular}

$\mathrm{CV}$, cardiovascular; BMI, body mass index; eGFR, estimated glomerular filtration rate

concerning CV outcome and sudden death. However, in our study, a threshold of 0.75 carried no significance, but the end point of our study was the occurrence of CV events rather than sudden death.

To the best of our knowledge, percentage data on the prevalence of elevated T-waves in ESRD patients do not exist. Elevated T-waves are often an expression of underlying hyperka- 
Fig. 3. Kaplan-Meier analysis of the $T: R$ ratio in inferior (a) and anterior (b) ECG leads and the occurrence of $\mathrm{CV}$ events. A T:R ratio $>0.6$ in inferior but not anterior leads was significantly related to CV events ( $p=0.03$ and $p=0.16$, respectively).

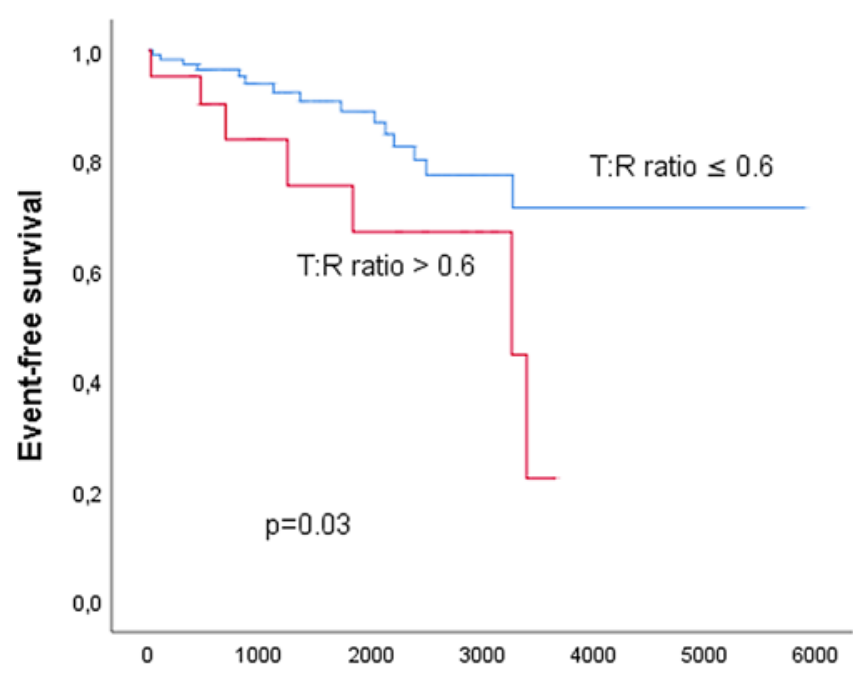

a

Days of observation

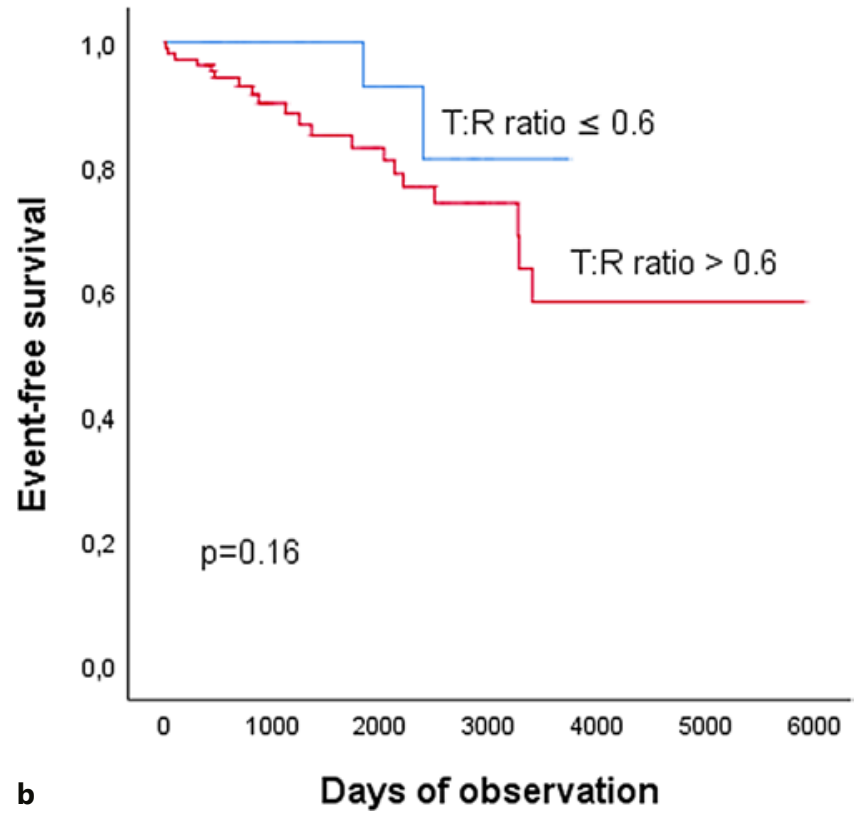

lemia, which is common in ESRD patients [24, 28, 29]. This association was confirmed in the present study, given our finding of a significant correlation between the T:R ratio in anterior leads and the serum potassium values. However, additional causes may also lead to elevated T-waves including LVH and the hyperacute phase of myocardial infarction. Furthermore, elevated T-waves can be observed in noninfarction myocardial ischemia and in young, athletic patients [30, 31]. In our study, we failed to observe a correlation between the T:R ratio and ECG signs of LVH. Also, it is unlikely that we recorded ECGs in the hyperacute phase of myocardial infarction, since our ECGs were recorded in a routine outpatient examination setting. 


\section{Kidney \\ Blood Pressure \\ Research}

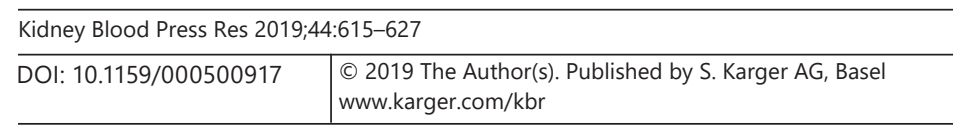

Buerschaper et al.: ECG and CV Events in ESRD

We also found that ECGs containing extrasystoles significantly predicted CV events, however, on univariate analysis only. This is probably due to the low number of cases in our study, since ECGs of only 4 patients contained extrasystoles. Further studies will be needed to confirm this correlation since studies concerning extrasystoles and outcome in ESRD patients are lacking as well.

Left and right Sokolow-Lyon indices in our study predicted outcomes again in univariate analysis only. Multivariate analysis did not show significance. In addition, a negative correlation between the Sokolow-Lyon index and the occurrence of CV events was observed. Our observation supports studies stating that the Sokolow-Lyon index represents a nonreliable parameter in predicting CV events in ESRD patients [19, 32].

In our study, only the $\mathrm{T}$ : $\mathrm{R}$ ratio was significant for $\mathrm{CV}$ events in regression analysis. Other ECG parameters were not significantly related to an increased frequency of CV events. Nevertheless, there was a trend toward a higher occurrence of prolonged QTc interval in ESRD patients developing CV events. In different studies, the QTc interval was reported to increase in dialysis patients $[33,34]$. A prolonged QTc interval like T-wave changes is known to be associated with an increased risk of sudden death and total mortality in hemodialysis patients [12].

Other studies found ECG changes like LVH by different scoring systems, increased heart rate, atrial fibrillation, PR-interval prolongation, and T-wave changes as significant parameters related to an increased CV morbidity and mortality and all-cause mortality in ESRD patients [13-20]. However, these were single studies focusing on selected parameters and in part using parameters, which are not measured in routine ECG evaluation. Sharma et al. [10] described an abnormal ECG including signs of LVH, ST depression or elevation, T-wave inversion or bundle branch block as an independent predictor of severe CAD in ESRD patients. These measures were not analyzed as single parameters but rather combined into an "abnormal ECG" if any of the mentioned parameters showed abnormalities. In contrast, our study analyzed all ECG parameters independently and performed a thorough evaluation of parameters, which are evaluated in daily routine.

There are various limitations to this study. Since we applied a retrospective study design, some transplantation files were missing or not usable due to bleaching of ECGs. Also only patients, who received a kidney transplant, were enrolled into the study. This is why patients, who died before kidney transplantation, possibly including sudden death, are not part of the study population. This may have led to a selection bias. Also, our cohort size may have been too small to detect other potentially relevant ECG parameters related to CV outcome or events of sudden death after transplantation. Nevertheless, the strength of our study is the thorough examination of all ECGs.

In conclusion, we present first evidence that an elevated $\mathrm{T}: \mathrm{R}$ ratio in particular in inferior ECG leads in ESRD patients on the kidney transplant list is predictive for CV events. If confirmed in independent studies, this easily available work-up may identify patients who may benefit from more sophisticated diagnostics to potentially reduce the occurrence of CV events.

\section{Acknowledgment}

None.

\section{Statement of Ethics}

Approval for the usage of transplantation files was confirmed by the respective hospital. The authors have no ethical conflicts to disclose. 


\section{Kidney \\ Blood Pressure Research}

\begin{tabular}{l|l}
\hline Kidney Blood Press Res 2019;44:615-627 \\
\hline DOI: 10.1159/000500917 & $\begin{array}{l}\text { @ 2019 The Author(s). Published by S. Karger AG, Basel } \\
\text { www.karger.com/kbr }\end{array}$ \\
\hline
\end{tabular}

Buerschaper et al.: ECG and CV Events in ESRD

\section{Disclosure Statement}

The authors have no conflicts of interest to declare.

\section{Funding Source}

None.

\section{Author Contributions}

Substantial contributions to the conception or design of the work: L.B., G.S., A.M., and J.F. Acquisition, analysis, or interpretation of data for the work: L.B. and G.S. Drafting the work: L.B. Revising the work critically for important intellectual content: G.S., J.F., and A.M. Final approval of the version to be published: L.B., G.S., J.F., and A.M. Agreement to be accountable for all aspects of the work in ensuring that questions related to the accuracy or integrity of any part of the work are appropriately investigated and resolved: L.B., G.S., J.F., and A.M.

\section{References}

1 Saran R, Li Y, Robinson B, Abbott KC, Agodoa LY, Ayanian J, et al. US Renal Data System 2015 Annual Data Report: Epidemiology of Kidney Disease in the United States. Am J Kidney Dis. 2016 Mar;67(3 Suppl 1):Svii, S1-305.

2 Go AS, Chertow GM, Fan D, McCulloch CE, Hsu CY. Chronic kidney disease and the risks of death, cardiovascular events, and hospitalization. N Engl J Med. 2004 Sep;351(13):1296-305.

3 Ojo AO, Hanson JA, Wolfe RA, Leichtman AB, Agodoa LY, Port FK. Long-term survival in renal transplant recipients with graft function. Kidney Int. 2000 Jan;57(1):307-13.

4 Kasiske BL, Maclean JR, Snyder JJ. Acute myocardial infarction and kidney transplantation. J Am Soc Nephrol. 2006 Mar;17(3):900-7.

5 Sarnak MJ, Levey AS, Schoolwerth AC, Coresh J, Culleton B, Hamm LL, et al.; American Heart Association Councils on Kidney in Cardiovascular Disease, High Blood Pressure Research, Clinical Cardiology, and Epidemiology and Prevention. Kidney disease as a risk factor for development of cardiovascular disease: a statement from the American Heart Association Councils on Kidney in Cardiovascular Disease, High Blood Pressure Research, Clinical Cardiology, and Epidemiology and Prevention. Hypertension. 2003 Nov;42(5):1050-65.

6 Wolfe RA, Ashby VB, Milford EL, Ojo AO, Ettenger RE, Agodoa LY, et al. Comparison of mortality in all patients on dialysis, patients on dialysis awaiting transplantation, and recipients of a first cadaveric transplant. $\mathrm{N}$ Engl J Med. 1999 Dec;341(23):1725-30.

7 Palepu S, Prasad GV. Screening for cardiovascular disease before kidney transplantation. World J Transplant. 2015 Dec;5(4):276-86.

8 Lentine KL, Costa SP, Weir MR, Robb JF, Fleisher LA, Kasiske BL, et al.; American Heart Association Council on the Kidney in Cardiovascular Disease and Council on Peripheral Vascular Disease. Cardiac disease evaluation and management among kidney and liver transplantation candidates: a scientific statement from the American Heart Association and the American College of Cardiology Foundation. J Am Coll Cardiol. 2012 Jul;60(5):43480.

9 Fleisher LA, Fleischmann KE, Auerbach AD, Barnason SA, Beckman JA, Bozkurt B, et al.; American College of Cardiology; American Heart Association. 2014 ACC/AHA guideline on perioperative cardiovascular evaluation and management of patients undergoing noncardiac surgery: a report of the American College of Cardiology/American Heart Association Task Force on practice guidelines. J Am Coll Cardiol. 2014 Dec;64(22):e77137.

10 Sharma R, Pellerin D, Gaze DC, Gregson H, Streather CP, Collinson PO, et al. Dobutamine stress echocardiography and the resting but not exercise electrocardiograph predict severe coronary artery disease in renal transplant candidates. Nephrol Dial Transplant. 2005 Oct;20(10):2207-14.

11 Abe S, Yoshizawa M, Nakanishi N, Yazawa T, Yokota K, Honda M, et al. Electrocardiographic abnormalities in patients receiving hemodialysis. Am Heart J. 1996 Jun;131(6):1137-44.

12 Genovesi S, Rossi E, Nava M, Riva H, De Franceschi S, Fabbrini P, et al. A case series of chronic haemodialysis patients: mortality, sudden death, and QT interval. Europace. 2013 Jul;15(7):1025-33.

13 Kim SJ, Oh HJ, Yoo DE, Shin DH, Lee MJ, Kim HR, et al. Electrocardiographic left ventricular hypertrophy and outcome in hemodialysis patients. PLoS One. 2012;7(4):e35534.

14 Cice G, Di Benedetto A, D'Andrea A, D'Isa S, De Gregorio P, Marcelli D, et al. Heart rate as independent prognostic factor for mortality in normotensive hemodialysed patients. J Nephrol. 2008 Sep-Oct;21(5):704-12. 
15 Waks JW, Tereshchenko LG, Parekh RS. Electrocardiographic predictors of mortality and sudden cardiac death in patients with end stage renal disease on hemodialysis. J Electrocardiol. 2016 Nov - Dec;49(6):848-54.

16 Flueckiger P, Pastan S, Goyal A, McClellan WW, Patzer RE. Associations of ECG interval prolongations with mortality among ESRD patients evaluated for renal transplantation. Ann Transplant. 2014 May;19:257-68.

17 Lin CY, Lin LY, Chen PC. Analysis of T-wave morphology from the 12-lead electrocardiogram for prediction of long-term prognosis in patients initiating haemodialysis. Nephrol Dial Transplant. 2007 Sep;22(9):2645-52.

18 Winkelmayer WC, Patrick AR, Liu J, Brookhart MA, Setoguchi S. The increasing prevalence of atrial fibrillation among hemodialysis patients. J Am Soc Nephrol. 2011 Feb;22(2):349-57.

19 Covic AC, Buimistriuc LD, Green D, Stefan A, Badarau S, Kalra PA. The prognostic value of electrocardiographic estimation of left ventricular hypertrophy in dialysis patients. Ann Noninvasive Electrocardiol. 2013 Mar; 18(2):188-98.

20 Patel RK, Mark PB, Halliday C, Steedman T, Dargie HJ, Cobbe SM, et al. Microvolt T-wave alternans in end-stage renal disease patients-associations with uremic cardiomyopathy. Clin J Am Soc Nephrol. 2011 Mar;6(3):51927.

21 Wang LW, Fahim MA, Hayen A, Mitchell RL, Baines L, Lord S, et al. Cardiac testing for coronary artery disease in potential kidney transplant recipients. Cochrane Database Syst Rev. 2011 Dec;(12):CD008691.

22 Secemsky EA, Verrier RL, Cooke G, Ghossein C, Subacius H, Manuchehry A, et al. High prevalence of cardiac autonomic dysfunction and T-wave alternans in dialysis patients. Heart Rhythm. 2011 Apr;8(4):592-8.

23 Aslam S, Friedman EA, Ifudu O. Electrocardiography is unreliable in detecting potentially lethal hyperkalaemia in haemodialysis patients. Nephrol Dial Transplant. 2002 Sep;17(9):1639-42.

24 Green D, Green HD, New DI, Kalra PA. The clinical significance of hyperkalaemia-associated repolarization abnormalities in end-stage renal disease. Nephrol Dial Transplant. 2013 Jan;28(1):99-105.

25 van Damr, Durrer D. The T wave and ventricular repolarization. Am J Cardiol. 1964 Sep;14(3):294-300.

26 Burgess MJ. Relation of ventricular repolarization to electrocardiographic $\mathrm{T}$ wave-form and arrhythmia vulnerability. Am J Physiol. 1979 Mar;236(3):H391-402.

27 Verrier RL, Klingenheben T, Malik M, El-Sherif N, Exner DV, Hohnloser SH, et al. Microvolt T-wave alternans physiological basis, methods of measurement, and clinical utility-consensus guideline by International Society for Holter and Noninvasive Electrocardiology. J Am Coll Cardiol. 2011 Sep;58(13):1309-24.

28 Rossignol P, Lamiral Z, Frimat L, Girerd N, Duarte K, Ferreira J, et al. Hyperkalaemia prevalence, recurrence and management in chronic haemodialysis: a prospective multicentre French regional registry 2-year survey. Nephrol Dial Transplant. 2017 Dec;32(12):2112-8.

29 Webster A, Brady W, Morris F. Recognising signs of danger: ECG changes resulting from an abnormal serum potassium concentration. Emerg Med J. 2002 Jan;19(1):74-7.

30 Pinto IJ, Nanda NC, Biswas AK, Parulkar VG. Tall upright T waves in the precordial leads. Circulation. 1967 Nov; 36(5):708-16.

31 Horwitz LD. Differential diagnosis of tall T waves in the resting electrocardiogram. South Med J. 1973 Aug; 66(8):873-7.

32 Agarwal R, Light RP. Determinants and prognostic significance of electrocardiographic left ventricular hypertrophy criteria in chronic kidney disease. Clin J Am Soc Nephrol. 2011 Mar;6(3):528-36.

33 Lorincz I, Mátyus J, Zilahi Z, Kun C, Karányi Z, Kakuk G. QT dispersion in patients with end-stage renal failure and during hemodialysis. J Am Soc Nephrol. 1999 Jun;10(6):1297-302.

34 Monfared A, Ghods AJ. Improvement of maximum corrected QT and corrected QT dispersion in electrocardiography after kidney transplantation. Iran J Kidney Dis. 2008 Apr;2(2):95-8. 